\title{
ELECTRICAL AND PHOTOELECTRIC PROPERTIES OF HETEROJUNCTIONS MoOx/n-Cd1-xZnxTe
}

\author{
(D)Mykhailo M. Solovana ${ }^{a}$, (D) Andrii I. Mostovyia ${ }^{a}$ (Dryhorii P. Parkhomenkoa,*, \\ (D) Viktor V. Brus ${ }^{b}$, (D) Pavlo D. Maryanchuk ${ }^{a}$ \\ ${ }^{a}$ Yuriy Fedkovych Chernivtsi National University \\ 2 Kotsyubinsky Str., 58012 Chernivtsi, Ukraine \\ ${ }^{b}$ Nazarbayev University, 53 Kabanbay Batyr, 010000, Nur-Sultan City, Kazakhstan \\ *Corresponding Author: h.parkhomenko@chnu.edu.ua
}

Received December 21, 2020; revised February 17, 2021; accepted February 18, 2021

\begin{abstract}
The paper presents the results of studies of the optical and electrical properties of $\mathrm{MoO}_{x} / \mathrm{n}-\mathrm{Cd}_{1-\mathrm{x}} \mathrm{Zn} \times \mathrm{Te}$ semiconductor heterojunctions made by depositing $\mathrm{MoO}_{x}$ films on a pre-polished surface of $n-\mathrm{Cd}_{1-\mathrm{x}} \mathrm{Zn}_{\mathrm{x}}$ Te plates $\left(5 \times 5 \times 0.7 \mathrm{~mm}^{3}\right)$ in a universal vacuum installation Leybold - Heraeus L560 using reactive magnetron sputtering of a pure Mo target. Such studies are of great importance for the further development of highly efficient devices based on heterojunctions for electronics and optoelectronics. The fabricated $\mathrm{MoO}_{\mathrm{x}} / \mathrm{n}-\mathrm{Cd}_{1-\mathrm{x}} \mathrm{Zn}_{\mathrm{x}} \mathrm{Te}$ heterojunctions have a large potential barrier height at room temperature $\left(\varphi_{0}=1.15 \mathrm{eV}\right)$, which significantly exceeds the analogous parameter for the $\mathrm{MoO}_{x} / \mathrm{n}-\mathrm{CdTe}$ heterojunction $\left(\varphi_{0}=0.85 \mathrm{eV}\right)$. The temperature coefficient of the change in the height of the potential barrier was experimentally determined to be $d\left(\varphi_{0}\right) / d T=-8.7 \cdot 10^{-3} \mathrm{eV} \mathrm{K}$, this parameter is four times greater than the temperature coefficient of change in the height of the potential barrier for $\mathrm{MoO}_{\mathrm{x}} / \mathrm{n}-\mathrm{CdTe}$ heterostructures. The greater value of the potential barrier height of the $\mathrm{MoO}_{\mathrm{x}} / \mathrm{n}-\mathrm{Cd}_{1-\mathrm{x}} \mathrm{Zn}_{\mathrm{x}}$ Te heterojunction is due to the formation of an electric dipole at the heterointerface due to an increase in the concentration of surface states in comparison with $\mathrm{MoO}_{\mathrm{x}} / \mathrm{n}-\mathrm{CdTe}$ heterostructures, and this is obviously associated with the presence of zinc atoms in the space charge region and at the metallurgical boundary section of the heteroboundary. In $\mathrm{MoO}_{\mathrm{x}} / \mathrm{n}-\mathrm{Cd}_{1-\mathrm{x}} \mathrm{Zn}_{\mathrm{x}} \mathrm{Te}$ heterojunctions, the dominant mechanisms of current transfer are generation-recombination and tunnelingrecombination with the participation of surface states, tunneling with forward bias, and tunneling with reverse bias. It was found that $\mathrm{MoO}_{\mathrm{x}} / \mathrm{n}-\mathrm{Cd}_{1-\mathrm{x}} \mathrm{Zn}_{\mathrm{x}} \mathrm{Te}$ heterojunctions, which have the following photoelectric parameters: open circuit voltage $\mathrm{V}_{\mathrm{oc}}=0.3 \mathrm{~V}$, short circuit current $\mathrm{I}_{\mathrm{sc}}=1.2 \mathrm{~mA} / \mathrm{cm}^{2}$, and fill factor $\mathrm{FF}=0.33$ at an illumination intensity of $80 \mathrm{~mW} / \mathrm{cm}^{2}$ are promising for the manufacture of detectors of various types of radiation. The measured and investigated impedance of the $\mathrm{MoO}_{\mathrm{x}} / \mathrm{n}-\mathrm{Cd}_{1-\mathrm{x}} \mathrm{Zn}_{\mathrm{x}} \mathrm{Te}$ heterojunction at various reverse biases, which made it possible to determine the distribution of the density of surface states and the characteristic time of their charge-exchange, which decrease with increasing reverse bias.
\end{abstract}

KEYWORDS: heterojunction, molybdenum oxide, $\mathrm{Cd}_{1-\mathrm{x}} \mathrm{Zn} \mathrm{n}_{\mathrm{x}} \mathrm{Te}$, impedance, surface states.

Телурид кадмію та тверді розчини на його основі $\mathrm{Cd}_{1-\mathrm{x}} \mathrm{Zn}_{\mathrm{x}} \mathrm{Te}$ є перспективними матеріалами для виготовлення приладів напівпровідникової мікроелектроніки [1]. Близькі до оптимальних значень для фотоелектричного перетворення енергії ширини заборонених зон $E_{g}=1,5$ eB (CdTe) та $E_{g}=1,5-1,55 \mathrm{eB}(\mathrm{CdZnTe})$ і високий коефіцієнт поглинання світла $\left(\alpha=10^{5} \mathrm{~cm}^{-1}\right.$ при енергії фотонів $\left.h v \geq E_{g}\right)$ сприяють застосуванню цих напівпровідників для створення сонячних елементів.

В свою чергу, оксиди перехідних металів, зокрема оксид молібдену, є одним з найбільш перспективним електронним матеріалом. Прозорі провідні шари широко використовуються для виготовлення приладів електроніки, оптоелектроніки та сонячної енергетики. В останні роки інтенсивно досліджуються напівпровідникові гетеропереходи на основі оксидів тонких плівок. $\mathrm{MoO}_{\mathrm{x}}$ прозорий в області видимого спектра, а також відносно добре проводить струм [2,3]. Відомо, що матеріали з великою роботою виходу здатні утворювати омічний контакт із широкозонними напівпровідниками р-типу провідності. Проте тонкі плівки 3 великою роботою виходу, нанесені на підкладки n-типу провідності, утворюють високоякісні випрямляючі діоди Шотткі або гетеропереходи [4,5]. Тому цікаво виготовити гетеропереходи де широкозонна провідна плівка оксиду молібдену забезпечить ефективне поглинання сонячного випромінювання фотоактивним шаром поглинача в широкому спектральному діапазоні.

Розвиток фізики і технології напівпровідникових гетеропереходів - один із основних напрямків досліджень у галузі сучасного матеріалознавства i напівпровідникового приладобудування. На даний час різні гетеропереходи широко застосовуються в електроніці, телекомунікаційних системах, лазерах і фотовольтаїці [6].

Таке зацікавлення до напівпровідникових приладів на основі гетеропереходів вимагає розвитку точних методів для дослідження їх електричних і фотоелектричних властивостей [7,8]. Однак, внаслідок деяких причин дослідження електричних властивостей гетеропереходів суттєво ускладнене порівняно з гомопереходами.

У більшості гетеропереходів неможливо уникнути розбіжності періодів кристалічних граток, що викликає появу різних поверхневих станів, в основному у вигляді дислокацій невідповідності. Поверхневі дефекти створюють енергетичні рівні в межах забороненої зони. Вони можуть працювати як рекомбінаційні центри або пастки, які чинять великий вплив на електричні властивості напівпровідникових приладів на основі гетеропереходів [9,10].

Імпеданс спектроскопія - це потужний інструмент для дослідження напівпровідникових матеріалів i структур на їх основі [9]. Цей метод дозволяє аналізувати окремо вплив різних компонент еквівалентної схеми напівпровідникової структури. Імпеданс спектроскопія широко використовується для дослідження (C) M. M. Solovan, A. I. Mostovyi, H. P. Parkhomenko, V. V. Brus, P. D. Maryanchuk, 2021 
напівпровідникових гетеропереходів, які є набагато складнішими для аналізу у порівнянні з гомопереходами, в основному внаслідок наявності поверхневих станів [9].

3 вище сказаного очевидно, що створення гетероструктур $\mathrm{MoO}_{\mathrm{x}} / \mathrm{n}-\mathrm{Cd}_{1-\mathrm{x}} \mathrm{Zn}_{\mathrm{x}} \mathrm{Te}$ та дослідження їх фізичних властивостей на постійному та змінному струмі є актуальною задачею.

\section{ЕКСПЕРИМЕНТАЛЬНА ЧАСТИНА}

Для виготовлення гетероструктури використовували кристали $\mathrm{Cd}_{1-\mathrm{x}} \mathrm{Zn}_{\mathrm{x}} \mathrm{Te}, 3$ малим вмістом $\mathrm{Zn}$, які були вирощені методом Бріджмена і мали мале значення питомого опору $\rho \approx 10^{2} \mathrm{OM} \cdot \mathrm{cm}$.

Структури виготовлялись нанесенням плівок $\mathrm{MoO}_{\mathrm{x}}$ на попередньо поліровану поверхню пластин $\mathrm{n}-\mathrm{Cd}_{1-\mathrm{x}} \mathrm{Zn}_{\mathrm{x}} \mathrm{Te}$ (розміром $5 \times 5 \times 0,7$ мм $^{3}$ ) в універсальній вакуумній установці Leybold - Heraeus L560 за допомогою реактивного магнетронного розпилення мішені чистого Мо в атмосфері суміші аргону і кисню, при постійній напрузі. Молібденова мішень - це пластина діаметром 100 мм і товщиною 5 мм. Розміщується вона на столику магнетрона 3 водяним охолодженням. Підкладка з $\mathrm{Cd}_{1-\mathrm{x}} \mathrm{Zn}_{\mathrm{x}} \mathrm{Te}$ розміщується над магнетроном на столику, який обертається. Це робиться для того, щоб забезпечити нанесення однорідних плівок. Перед початком процесу напилення у вакуумній камері понижають тиск до $10^{-4}$ Па.

Формування газової суміші Ar i $\mathrm{O}_{2}$, в необхідних пропорціях відбувається 3 двох окремих балонів, перед процесом напилення.

Для видалення забруднення поверхні мішені і підкладки, використовували короткочасне бомбардування іонами Ar. Під час процесу напилення, парціальні тиски у вакуумній камері встановлюються 0,34 Па для Ar i 0,024 Па для $\mathrm{O}_{2}$. Потужність магнетрона - 120 Вт. Процес напилення проходив протягом 10 хвилин, при температурі підкладки $250{ }^{\circ} \mathrm{C}$.

Були напилені тонкі плівки $\mathrm{MoO}_{\mathrm{x}}$ на скляні та керамічні підкладки, для визначення оптичних і електричних параметрів тонких плівок. Отримані плівки володіли провідністю n-типу. Виміряні значення питомої електропровідності і концентрації носіїв заряду становили $\sigma=10 \quad \mathrm{OM}^{-1} \cdot \mathrm{cm}^{-1} \mathrm{i} \mathrm{n}=4,8 \cdot 10^{17} \mathrm{~cm}^{-3}$, при $295 \mathrm{~K}$.

Методом магнетронного розпилення молібдену формували фронтальний електричний контакт 3 тонкою плівкою оксиду молібдену, при температурі підкладки $150^{\circ} \mathrm{C}$. При формуванні тилового електричного контакту до підкладки n-CdZnTe осаджували шар $\mathrm{Cu}$ шляхом відновлення 3 водного розчину $\mathrm{CuSO}_{4} 3$ подальшим вплавлюванням індію.

\section{РЕЗУЛЬТАТИ ТА ЇХ ОБГОВОРЕННЯ}

\section{Електричні та фотоелектричні властивості}

Як видно з рис. 1, при освітленні білим світлом інтенсивністю 80 мВт/см², зворотний струм $I_{\text {light }}$ зростає у порівнянні з його величиною у темряві $I_{d a r k}$. 3 ВАХ освітленого гетеропереходу $\mathrm{MoO}_{\mathrm{x}} / \mathrm{n}-\mathrm{Cd}_{1-\mathrm{x}} \mathrm{Zn}_{\mathrm{x}} \mathrm{Te}($ рис. 1$)$ видно, що він володіє такими фотоелектричними параметрами: напруга холостого ходу $V_{o c}=0,3 \mathrm{~B}$, струм короткого замикання $I_{s c}=1,2 \mathrm{MA} / \mathrm{cm}^{2}$ і коефіцієнт заповнення $\mathrm{FF}=0,33$ при інтенсивності освітлення $80 \mathrm{mBT} / \mathrm{cm}^{2}$.

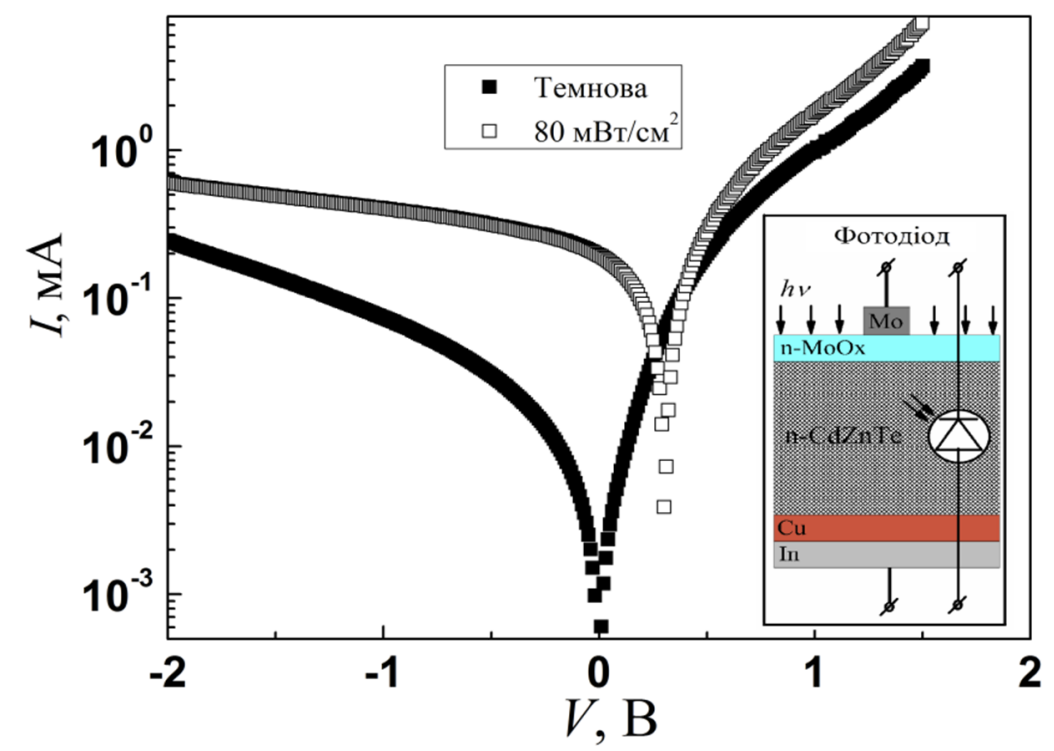

Рис. 1. ВАХ гетеропереходу $\mathrm{MoO}_{\mathrm{x}} / \mathrm{n}-\mathrm{Cd}_{1-\mathrm{x}} \mathrm{Zn}_{\mathrm{x}}$ Те неосвітленого та при інтенсивності освітлення 80 мBт/см² На вставці приведено структурну схему гетероструктури $\mathrm{MoO}_{\mathrm{x}} / \mathrm{n}-\mathrm{Cd}_{1-\mathrm{x}} \mathrm{Zn}_{\mathrm{x}} \mathrm{Te}$.

Четвертий квадрант ( $V_{o c} \geq V \geq 0$ ) освітленої ВАХ $€$ найбільш важливим, так як він визначає всі фотоелектричні параметри (рис. 2). Враховуючи рівняння, яке описує струм через гетероструктуру у темнових умовах, ми можемо записати вираз для освітленої ВАХ на основі еквівалентної схеми гетеропереходу (вставка рис. 2) з урахуванням впливу послідовного $R_{s}$ і шунтуючого $R_{s h}$ опорів: 


$$
I=I_{p h}-I_{0}\left[\exp \left(\frac{e\left(V-I R_{s}\right)}{n k T}\right)-1\right]-\frac{V+I R_{s}}{R_{s h}},
$$

де $I_{0}$ - струм насичення, $\mathrm{n}$ - показник неідеальності, а $R_{s}$ та $R_{s h}$ послідовний і шунтуючий опори (вставка. рис. 2 ), $I_{p h}$ - фотострум.

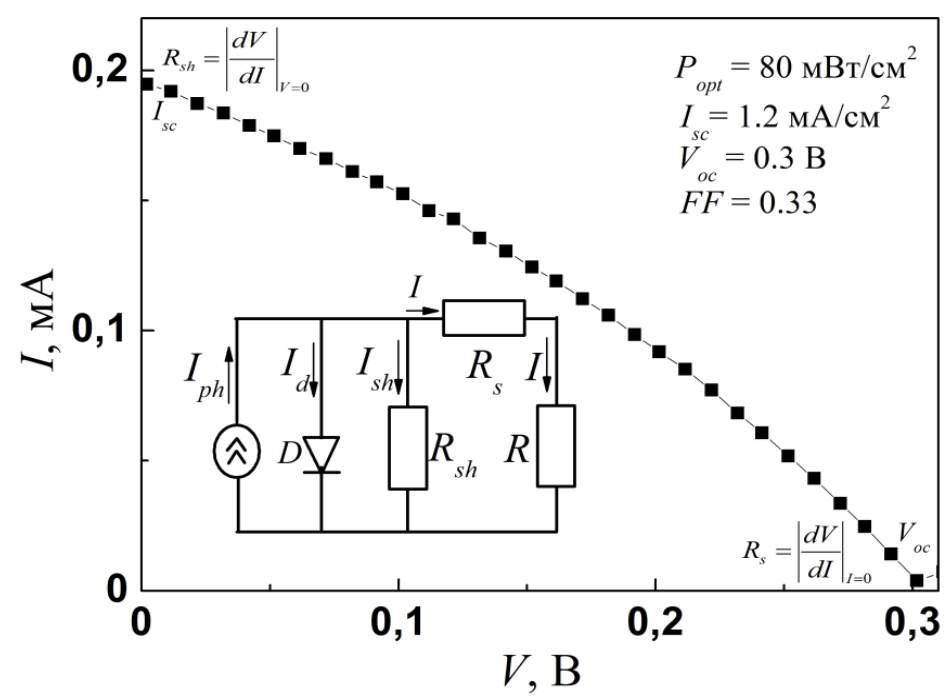

Рис. 2. Четвертий квадрант освітленої ВАХ $\mathrm{MoO}_{x} / \mathrm{n}-\mathrm{Cd}_{1-\mathrm{x}} \mathrm{Zn}_{\mathrm{x}} \mathrm{Te}$.

На вставці наведено еквівалентну схему освітленого гетеропереходу.

На рис. 3 представлено темнові вольт-амперні характеристики гетероструктури $\mathrm{MoO}_{\mathrm{x}} / \mathrm{n}-\mathrm{Cd}_{1-\mathrm{x}} \mathrm{Zn}$ 的 при різних температурах, у напівлогарифмічному масштабі. Досліджувана структура володіє яскраво вираженою діодною характеристикою з коефіцієнтом випрямлення $k \approx 10^{2}$.

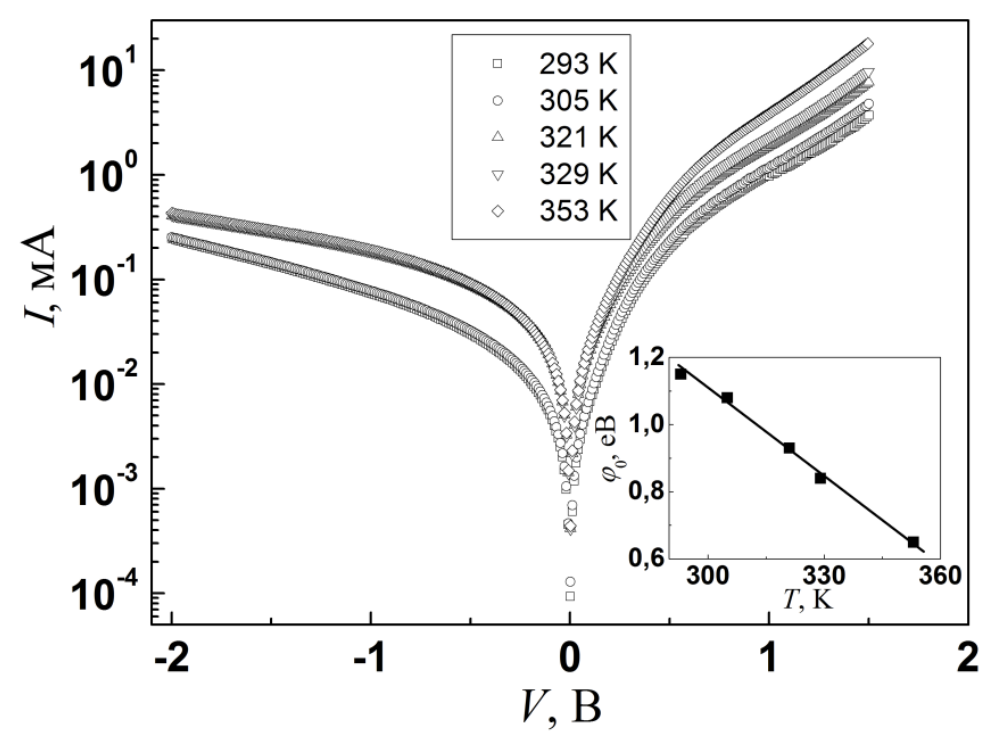

Рис. 3. Темнові ВАХ гетероструктури $\mathrm{n}-\mathrm{MoO}_{\mathrm{x}} / \mathrm{n}-\mathrm{Cd}_{1-\mathrm{x}} \mathrm{Zn} \mathrm{x}$ Те при різних температурах у напівлогарифмічному масштабі. На вставці - температурна залежність висоти потенціального бар'єру.

Прямі гілки ВАХ досліджуваної структури, виміряні при різних температурах, наведені на рис. 3. Для них характерно зменшення напруги, при якій спостерігається швидке зростання струму з підвищенням температури, внаслідок зниження потенціального бар'єру, обумовленого контактною різницею потенціалів та збільшення концентрації електронів. Шляхом екстраполяції лінійних ділянок вольт-амперних характеристик до перетину 3 віссю напруг, визначені значення висоти потенціального бар'єру $\varphi_{0}$ гетеропереходу при різних температурах (вставка рис. 3).

Варто відмітити, що визначена висота потенціального бар'єру гетеропереходу $\mathrm{MoO}_{\mathrm{x}} / \mathrm{n}-\mathrm{Cd}_{1-\mathrm{x}} \mathrm{Zn}$ 的 при кімнатній температурі $\left(\varphi_{0}=1,15 \mathrm{eB}\right)$ значно перевищує аналогічний параметр для гетеропереходу $\mathrm{MoO}_{\mathrm{x}} / \mathrm{n}-\mathrm{CdTe}$ $\left(\varphi_{0}=0,85 \mathrm{eB}\right)$. Експериментально визначений температурний коефіцієнт зміни висоти потенціального бар'єра 
становив $d\left(\varphi_{0}\right) / d T=-8.7 \cdot 10^{-3} \mathrm{eB} / \mathrm{K}$, однак даний параметр більший у чотири рази від температурного коефіцієнта зміни висоти потенціального бар'єра для гетероструктур $\mathrm{MoO}_{\mathrm{x}} / \mathrm{n}-\mathrm{CdTe}$. Більше значення висоти потенціального бар'єру гетеропереходу $\mathrm{MoO}_{\mathrm{x}} / \mathrm{Cd}_{1-\mathrm{x}} \mathrm{Zn}_{\mathrm{x}} \mathrm{Te}$ обумовлене формуванням електричного диполя на гетерограниці, внаслідок збільшення концентрації поверхневих станів в порівнянні з гетероструктурою $\mathrm{MoO}_{\mathrm{x}} / \mathrm{n}-\mathrm{CdTe}$, а це очевидно пов'язано з наявністю атомів цинку в області просторового заряду та на металургійній межі поділу гетерограниці. Невеликий вміст атомів цинку практично не змінює ширину забороненої зони твердого розчину $\mathrm{Cd}_{1-\mathrm{x}} \mathrm{Zn}_{\mathrm{x}} \mathrm{Te}$ по відношенню до $\mathrm{CdTe}$. Тому можна припустити, що наявність атомів цинку призводить до формування енергетичних рівнів розміщених в околі гетерограниці $\mathrm{MoO}_{\mathrm{x}} / \mathrm{Cd}_{1-\mathrm{x}} \mathrm{Zn}_{\mathrm{x}} \mathrm{Te}$, які формують вище згаданий електричний диполь, а збільшення температурного коефіцієнта зміни висоти потенціального бар'єру обумовлене зменшенням цього диполя при зростанні температури через виснаження енергетичних рівнів, які його утворюють. Формування електричного диполя на гетерограниці також спостерігалося нами при виготовленні гетероструктури $\mathrm{TiN} / \mathrm{p}-\mathrm{Cd}_{1-\mathrm{x}} \mathrm{Zn}_{\mathrm{x}} \mathrm{Te}$ [11].

\section{Механізми струмопереносу}

Аналіз прямих гілок $\mathrm{BAX}$ структур $\mathrm{MoO}_{\mathrm{x}} / \mathrm{n}-\mathrm{Cd}_{1-\mathrm{x}} \mathrm{Zn}_{\mathrm{x}} \mathrm{Te}$, побудованих в напівлогарифмічному масштабі, показав, що на залежності $\ln I=\mathrm{f}(V)$ спостерігається три прямолінійні ділянки, що свідчить про три домінуючих механізми струмопереносу. Отримане значення коефіцієнта неідеальності $n$ для трьох ділянок напруг (рис. 4): n змінюється від 3,6 до 3,3 (3kT/e $<V<0,3$ В) з підвищенням температури від 294-350 К, становить $n \approx 6(0,3<\mathrm{V}<0,6 \mathrm{~B})$ і становить $n>10(\mathrm{~V}>0,6 \mathrm{~B})$.

Значення показника неідеальності в області напруг $3 k T / e<V<0,3 \mathrm{~B}$ близькі до 2 дають можливість припустити, що основний механізм струмопереносу визначається генераційно-рекомбінаційними процесами в області просторового заряду, а саме n змінюється від 3,6 до 3,3 з підвищенням температури в інтервалі 295-358 К (вставка рис. 4), це свідчить про те, що у вище запропонований домінуючий механізм струмопереносу, який обумовлений генераційно-рекомбінаційними процесами в області просторового заряду, роблять внесок електрично активні поверхневі стани розміщені на металургійній межі розділу досліджуваного гетеропереходу [12,13].

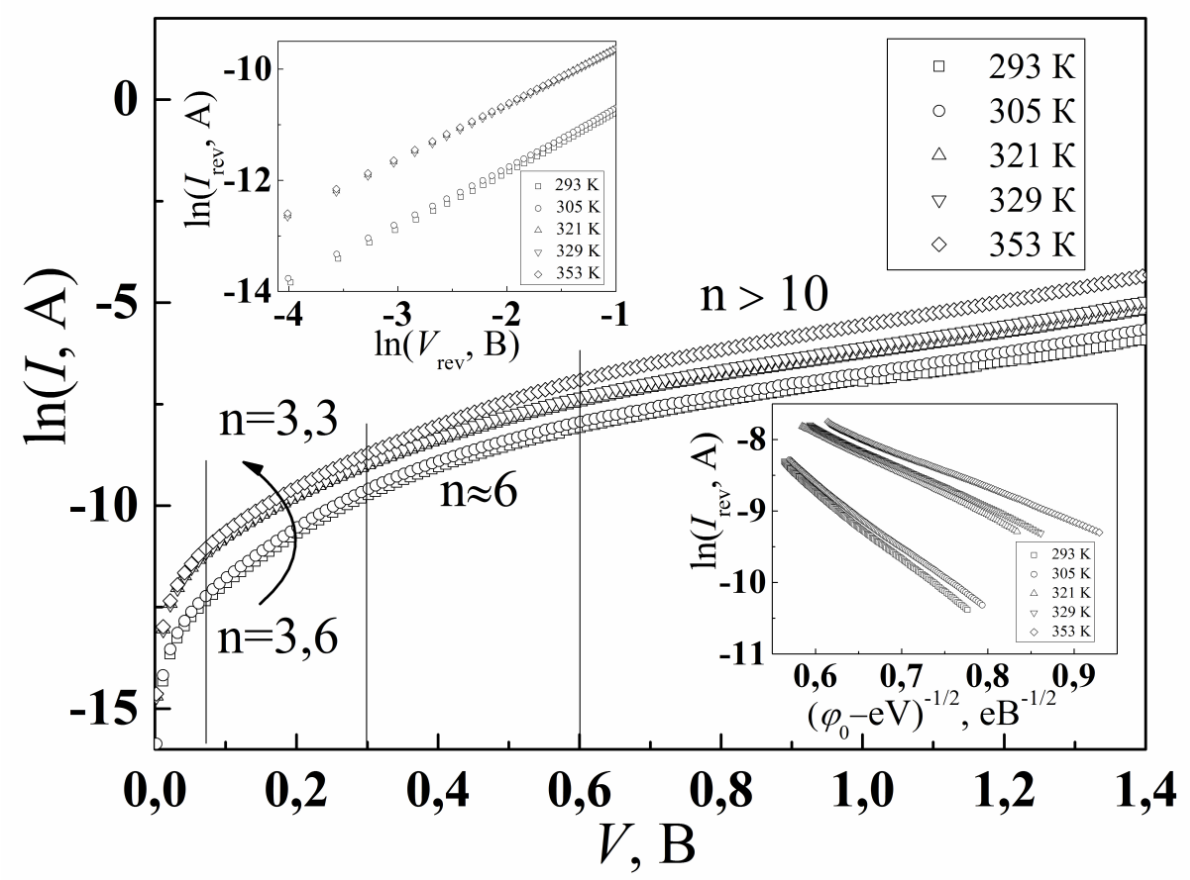

Рис. 4. Темнові ВАХ гетероструктури n-MoOx $/ \mathrm{n}-\mathrm{Cd}_{1-\mathrm{x}} \mathrm{Zn}_{\mathrm{x}}$ Те при різних температурах у напівлогарифмічному масштабі. На вставках - приведено залежності, які описують механізми струмопереносу через гетероструктуру при зворотному зміщенні.

При збільшенні прямого зміщення показник неідеальності зростає до $n \approx 6(0,3<\mathrm{V}<0,6 \mathrm{~B})$, це свідчить про наявність тунельного струму [14], оскільки потенціальний бар'єр ще достатньо великий для прямого тунелювання носіїв заряду, єдиним фізично обгрутнованим механізмом струмопереносу у досліджуваній області напруг $є$ тунельно-рекомбінаційні процеси за участі поверхневих станів [14], а при збільшенні прямого зміщення $\mathrm{V}>0,6$ В показник неідеальності ще зростає і становить більше 10, це свідчить що настають умови сприятливі для прямого тунелювання носіїв заряду через потенціальний бар'єр.

Проведений аналіз механізмів струмопереносу через досліджувану гетероструктуру $\mathrm{MoO}_{\mathrm{x}} / \mathrm{n}-\mathrm{Cd}_{1-\mathrm{x}} \mathrm{Zn}_{\mathrm{x}} \mathrm{Te}$ показав, що при малих зворотних напругах $3 k T / e<V_{\text {rev }}<0,5$ В залежність струму від напруги описується степеневим законом $I \sim V^{m}$, побудувавши залежності $\ln \left(I_{\mathrm{rev}}\right)=f\left(\ln V_{\mathrm{rev}}\right)$ визначено значення $m=1$ (вставка рис.4). 
Це відповідає струмам витоку через шунтуючий опір, а при більших зворотних зміщеннях, апроксимація зворотних гілок ВАХ прямими лініями в координатах $\ln \left(I_{\text {rev }}\right)=\mathrm{f}\left(\varphi_{0}-e V\right)^{-1 / 2}$ (вставка рис. 4) свідчить про домінування тунельного механізму струмопереносу [14].

\section{Імпеданс спектроскопія}

Імпеданс напівпровідникових гетеропереходів $\mathrm{MoO}_{\mathrm{x}} / \mathrm{n}-\mathrm{Cd}_{1-\mathrm{x}} \mathrm{Zn}_{\mathrm{x}}$ Те розглянуто при наявності послідовного $R_{s}$ і шунтуючого $R_{s h}$ опорів, паразитної індуктивності $L$ і континууму поверхневих станів. Еквівалентна схема досліджуваного гетеропереходу представлена на рис. 5.

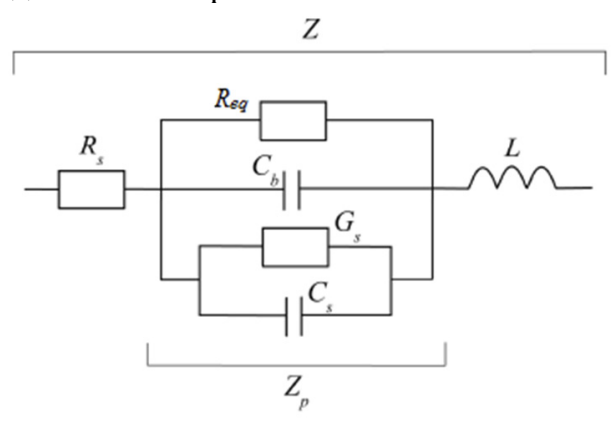

Рис. 5. Еквівалентна схема напівпровідникового гетеропереходу при наявності континууму поверхневих станів: $R_{s}$ - послідовний опір, $R_{e q}=R_{s h} R_{b} /\left(R_{s h}+R_{b}\right)$ - еквівалентний опір, $R_{s h}-$ шунтуючий опір, $R_{b}-$ бар'єрний опір, $C_{b}-$ бар'єрна ємність, $G_{s}$ - провідність континууму поверхневих станів, $C_{s}-\epsilon$ мність континууму поверхневих станів, $L-$ індуктивність.

Відомо, що комплексна провідність континууму поверхневих станів описується наступним виразом [15]:

$$
Y_{s}=\frac{e N_{s s} S}{2 \tau_{m}} \ln \left(1+\omega^{2} \tau_{m}^{2}\right)+i \frac{e N_{s s} S}{\tau_{m}} \arctan \left(\omega \tau_{m}\right),
$$

де $N_{s s}$ - розподіл густини поверхневих станів $\left[\mathrm{cm}^{-2} \mathrm{eB}^{-1}\right], \tau_{m}$ - характеристичний час у рамках моделі континууму поверхневих станів, $S$ - площа напівпровідникового гетеропереходу, $e$ - заряд електрона, $\omega$ - циклічна частота змінного сигналу. Таким чином, компоненти гілки континууму поверхневих станів: провідність $G_{s}$ та ємність $C_{s}$ визначаються виразами (2) і (3), відповідно:

$$
\begin{aligned}
& G_{s}=\frac{e N_{s s} S}{2 \tau_{m}} \ln \left(1+\omega^{2} \tau_{m}^{2}\right), \\
& C_{s}=\frac{e N_{s s} S}{\omega \tau_{m}} \arctan \left(\omega \tau_{m}\right) .
\end{aligned}
$$

Варто відмітити, що вираз (1) записаний з урахуванням рівномірного розподілу густини поверхневих станів в околі $k T / e$ в околі рівня Фермі, а не в межах усієї забороненої зони, що прийнятно для багатьох реальних систем.

Остаточно можна записати вираз для імпедансу напівпровідникового гетеропереходу при наявності послідовного $R_{s}$ і шунтуючого опору $R_{s h}$, паразитної індуктивності і континууму поверхневих станів $N_{s s}, \tau_{m}$ $[16,17,18]$ :

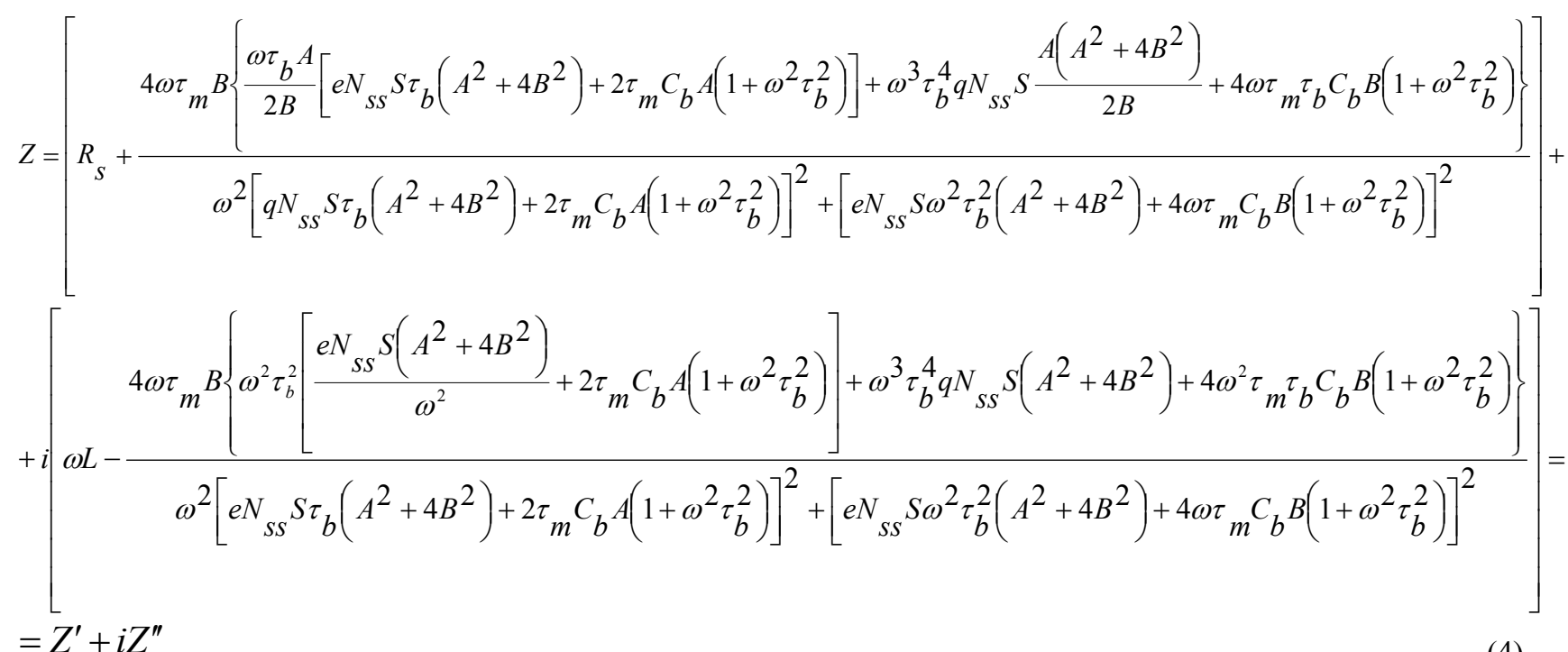


де $\tau_{b}=R_{e q} C_{b}, A=\ln \left(1+\omega^{2} \tau_{m}^{2}\right), B=\arctan \left(\omega \tau_{m}\right), Z^{\prime}$ і $Z^{\prime \prime}$ - дійсна і уявна частина імпедансу напівпровідникових гетеропереходів, розглянутих у рамках моделі континууму поверхневих станів.

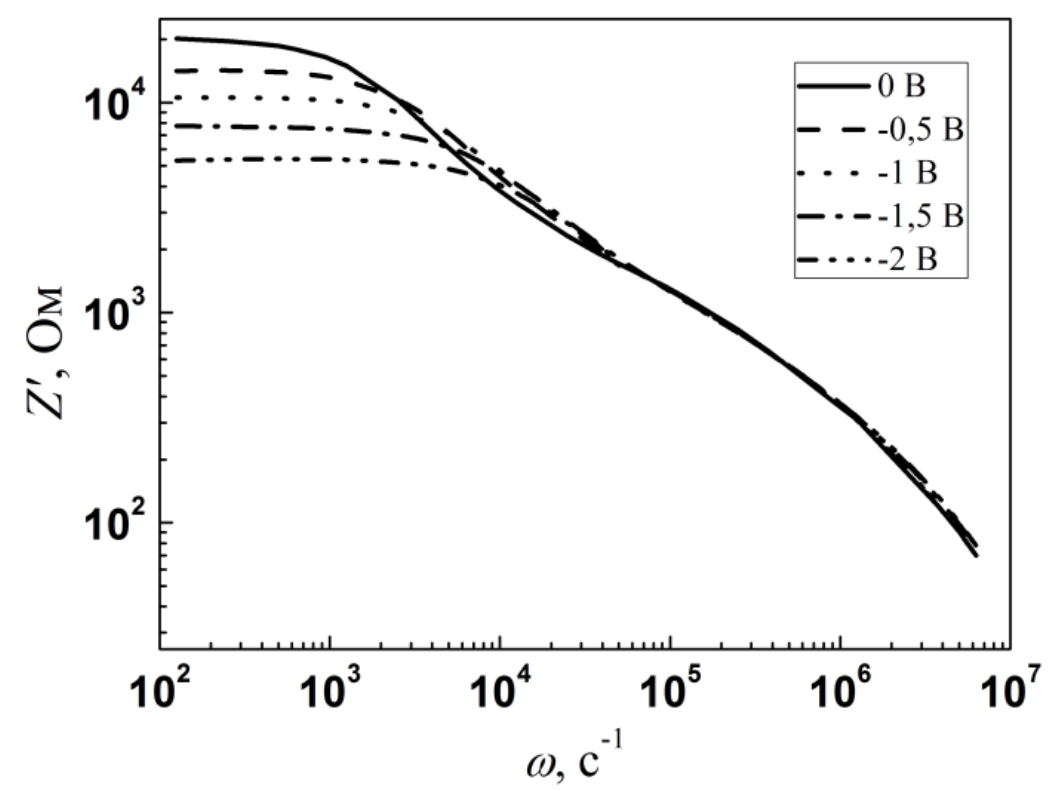

Рис. 6. Спектральний розподіл дійсної компоненти імпедансу гетеропереходу $\mathrm{MoO}_{\mathrm{x}} / \mathrm{n}-\mathrm{Cd}_{1-\mathrm{x}} \mathrm{Zn} \mathrm{x}$ Te при різних зворотних зміщеннях.

Спектральний розподіл дійсної і уявної частини імпедансу гетеропереходу $\mathrm{MoO}_{\mathrm{x}} / \mathrm{n}-\mathrm{Cd}_{1-\mathrm{x}} \mathrm{Zn}_{\mathrm{x}} \mathrm{Te}$ при різних зворотних зміщеннях показано на рис. 6 і 7, відповідно. 3 рисунків видно, що вплив континууму поверхневих станів на дійсну та уявну частину імпедансу спостерігається лише при циклічній частоті змінного сигналу $\omega \leq 1 / \tau_{m}=1 \cdot 10^{5} \mathrm{c}^{-1}$, це свідчить про те, що поверхневі стани відносно повільні і не встигають перезаряджатися, тобто не встигають слідувати за високочастотним змінним сигналом.

Комплексна провідність паралельної гілки еквівалентної схеми, зображеної на рис. $5, Y_{p}$ описується виразом через дійсну і уявну частини імпедансу $Z^{\prime}$ і $Z^{\prime \prime}$, а на основі виразів для дійсної частини провідності записують наступне рівняння [19,20]:

$$
\frac{1}{\omega}\left[\frac{Z^{\prime}-R_{s}}{\left[Z^{\prime}-R_{s}\right]^{2}+\left[Z^{\prime \prime}-\omega L\right]^{2}}-\frac{1}{R_{s h}}\right]=\frac{e N_{s s} S}{2 \omega \tau_{m}} \ln \left(1+\omega^{2} \tau_{m}^{2}\right) .
$$

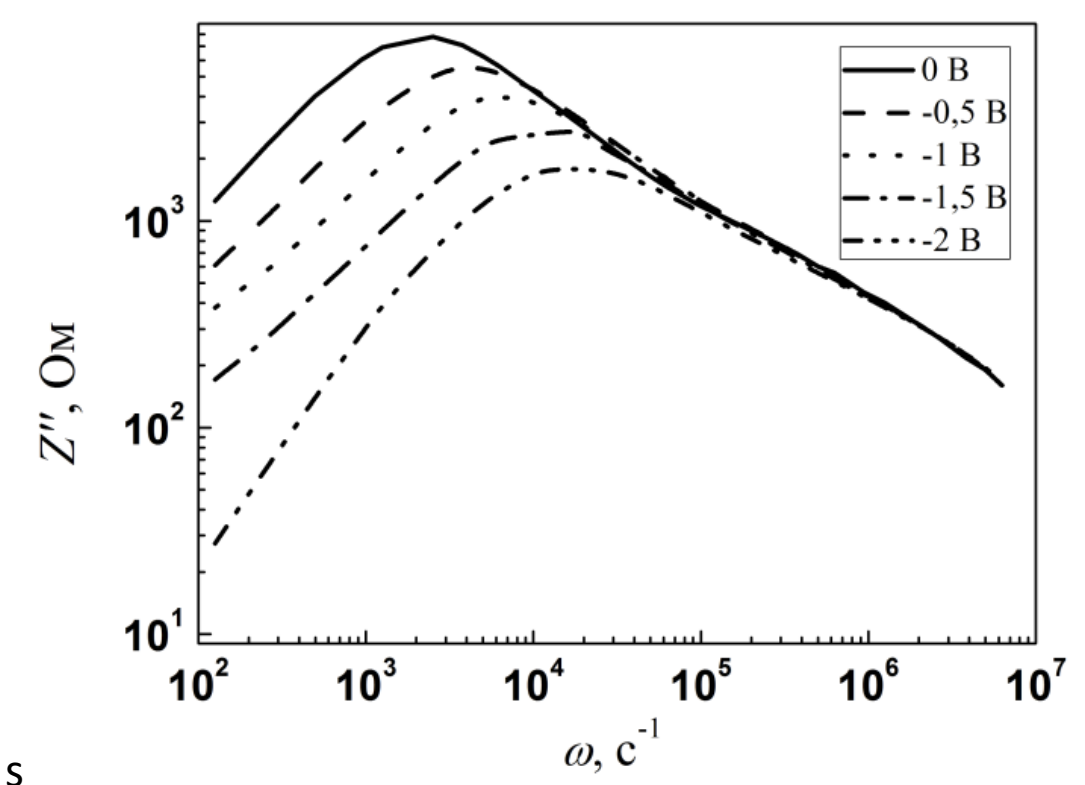

Рис. 7. Спектральний розподіл уявної компоненти імпедансу гетеропереходу $n-\mathrm{MoO}_{\mathrm{x}} / \mathrm{n}-\mathrm{Cd}_{1-\mathrm{x}} \mathrm{Zn} \mathrm{x}_{\mathrm{x}} \mathrm{Te}$ при різних зворотних зміщеннях. 


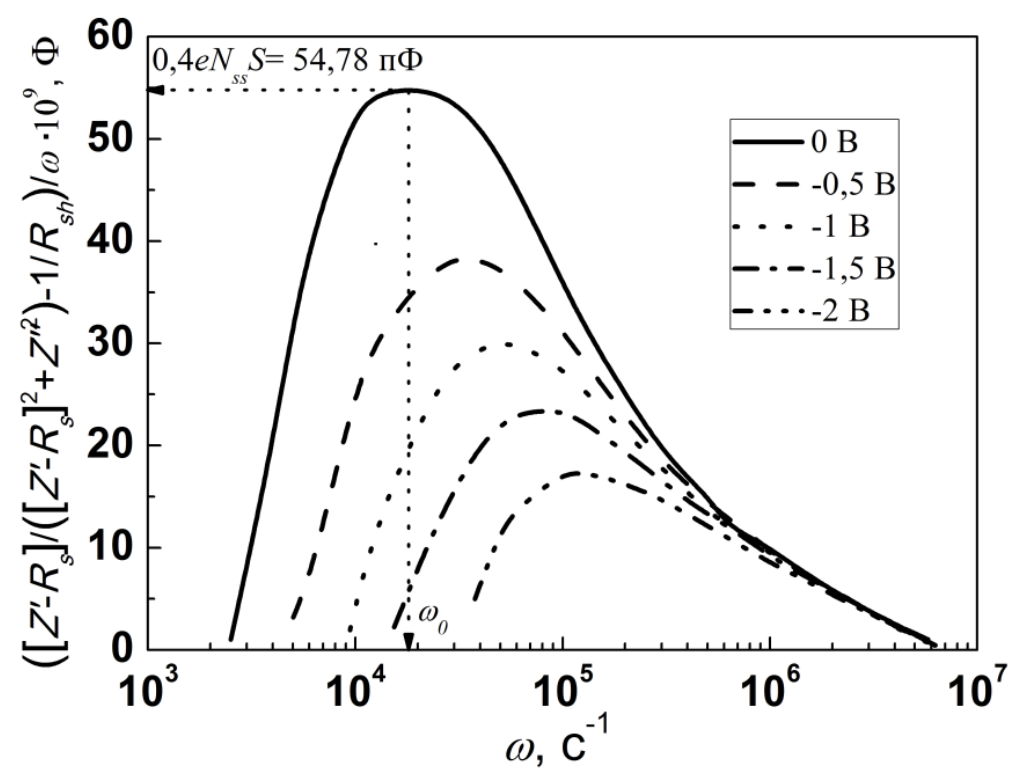

Рис. 8. Визначення параметрів пов'язаних з поверхневими станами в рамках моделі континууму поверхневих станів.

3 виразу (5) видно, що із графіка $\left\{\left[Z^{\prime}-R_{s}\right] /\left(\left[Z^{\prime}-R_{s}\right]^{2}+\left[Z^{\prime \prime}-\omega L\right]^{2}\right)-1 / R_{s h}\right\} / \omega$ від $\omega$ можна визначити обидва параметри пов'язані з континуумом поверхневих станів при фіксованому зміщенні:

$$
\begin{gathered}
\tau_{m}=\frac{1.977}{\omega_{0}}, \\
N_{s s}=\frac{\left\{\frac{1}{\omega}\left[\frac{\left(Z^{\prime}-R_{s}\right)}{\left(Z^{\prime}-R_{s}\right)^{2}+\left(Z^{\prime \prime}-\omega L\right)^{2}}-\frac{1}{R_{s h}}\right]\right\}}{0.402 e S} .
\end{gathered}
$$

Використовуючи рівняння (6-7) та (рис. 8) визначено розподіл густини поверхневих станів $N_{s s}$ та характеристичного часу $\tau_{m}$ У залежності від прикладеного зовнішнього зміщення, які приведено на рис. 9.

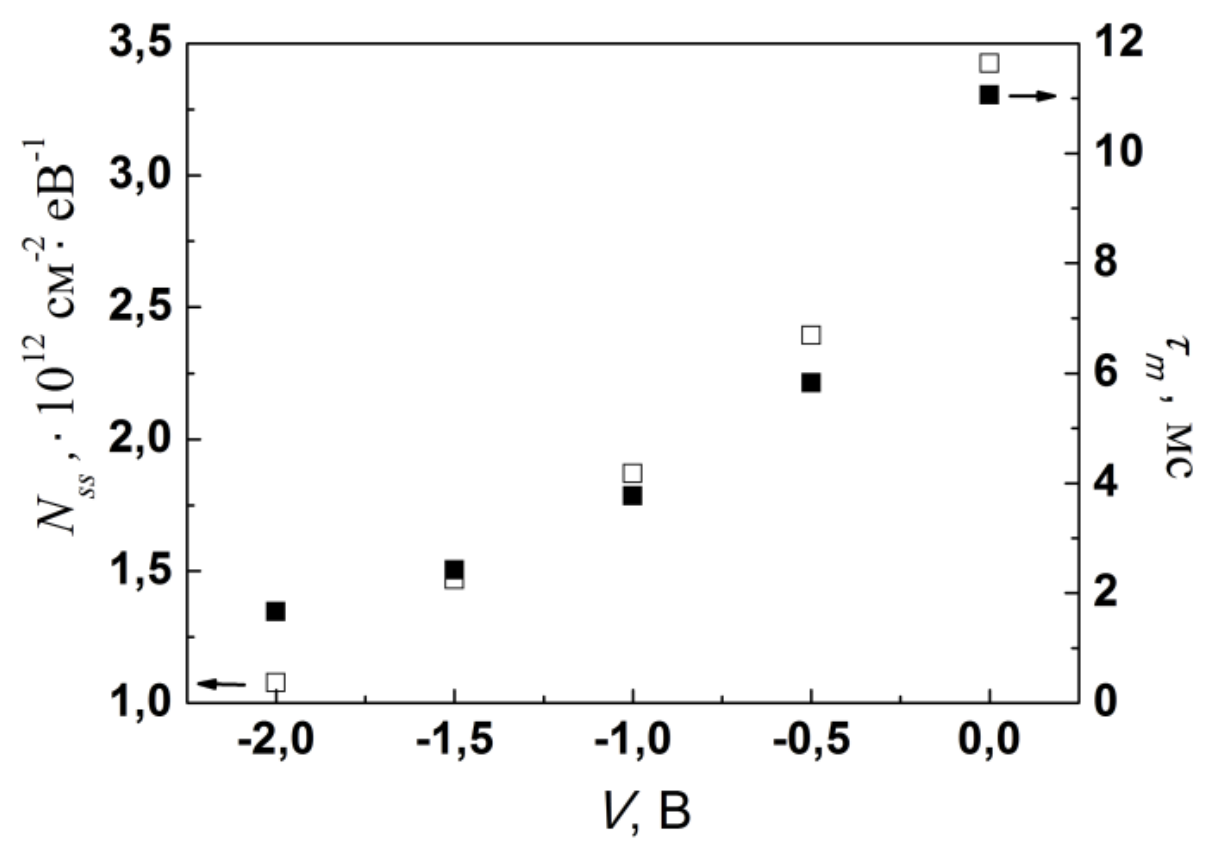

Рис. 9. Розподіл густини поверхневих станів $N_{s s}$ та характеристичного часу $\tau_{m}$

3 рис. 9 видно, що зі збільшенням зворотного зміщення зменшується густина поверхневих станів $N_{s s}$ та характеристичний час їх перезарядки $\tau_{m}$, що обумовлено зміщенням положення рівня Фермі в межах забороненої зони кадмій цинк телуру на гетерограниці $\mathrm{MoO}_{\mathrm{x}} / \mathrm{n}-\mathrm{Cd}_{1-\mathrm{x}} \mathrm{Zn}_{\mathrm{x}} \mathrm{Te}$. 


\section{ВИСНОВКИ}

Встановлено, що виготовлені гетеропереходи $\mathrm{MoO}_{\mathrm{x}} / \mathrm{n}-\mathrm{Cd}_{1-\mathrm{x}} \mathrm{Zn}_{\mathrm{x}} \mathrm{Te}$ володіють великою висотою потенціального бар'єру при кімнатній температурі ( $\left.\varphi_{0}=1,15 \mathrm{eB}\right)$, яка значно перевищує аналогічний параметр для гетеропереходу $\mathrm{MoO}_{\mathrm{x}} / \mathrm{n}-\mathrm{CdTe}\left(\varphi_{0}=0,85 \mathrm{eB}\right)$. Експериментально визначений температурний коефіцієнт зміни висоти потенціального бар'єра становив $d\left(\varphi_{0}\right) / d T=-8.7 \cdot 10^{-3} \mathrm{eB} / \mathrm{K}$, однак даний параметр більший у чотири рази від температурного коефіцієнта зміни висоти потенціального бар'єра для гетероструктур $\mathrm{MoO}_{\mathrm{x}} / \mathrm{n}-\mathrm{CdTe}$. Більше значення висоти потенціального бар'єру гетеропереходу $\mathrm{MoO}_{\mathrm{x}} / \mathrm{n}-\mathrm{Cd}_{1-\mathrm{x}} \mathrm{Zn}_{\mathrm{x}} \mathrm{Te}$ обумовлене формуванням електричного диполя на гетерограниці, через збільшення концентрації поверхневих станів в порівнянні 3 гетероструктурою $\mathrm{MoO}_{\mathrm{x}} / \mathrm{n}-\mathrm{CdTe}$, а це очевидно пов'язано з наявністю атомів цинку в області просторового заряду та на металургійній межі поділу гетерограниці.

Показано, що в гетеропереходах $\mathrm{MoO}_{\mathrm{x}} / \mathrm{n}-\mathrm{Cd}_{1-\mathrm{x}} \mathrm{Zn}_{\mathrm{x}} \mathrm{Te}$ домінуючими механізмами струмопереносу $\epsilon$ генераційно-рекомбінаційний та тунельно-рекомбінаційний за участі поверхневих станів та тунельний при прямому зміщенні та тунелювання при зворотному зміщенні. Встановлено, що гетеропереходи $\mathrm{MoO}_{\mathrm{x}} / \mathrm{n}$ $\mathrm{Cd}_{1-\mathrm{x}} \mathrm{Zn}_{\mathrm{x}} \mathrm{Te}$, які володіють такими фотоелектричними параметрами: напруга холостого ходу $V_{\text {oc }}=0,33 \mathrm{~B}$, струм короткого замикання $I_{s c}=1,2 \mathrm{~mA} / \mathrm{cm}^{2}$ i коефіцієнт заповнення $\mathrm{FF}=0,33$ при інтенсивності освітлення $80 \mathrm{mBT} / \mathrm{cm}^{2}$ $\epsilon$ перспективними для виготовлення детекторів різного типу випромінювань.

Досліджено імпеданс гетеропереходу $\mathrm{MoO}_{\mathrm{x}} / \mathrm{n}-\mathrm{Cd}_{1-\mathrm{x}} \mathrm{Zn}_{\mathrm{x}} \mathrm{Te}$ при різних зворотних зміщеннях, що дало змогу визначити розподіл густини поверхневих станів та характеристичний час їх перезарядки, які зменшуються при зростанні зворотного зміщення.

\section{ORCID IDs}

(D)Mykhailo M. Solovan, https://orcid.org/0000-0002-1077-5702; (DAndrii I. Mostovyi, https://orcid.org/0000-0001-9634-0058 CHryhorii P. Parkhomenko, https://orcid.org/0000-0001-5358-1505; (DViktor V. Brus, https://orcid.org/0000-0002-8839-124X (D) Pavlo D. Maryanchuk, https://orcid.org/0000-0002-5523-4280

\section{REFERENCES}

[1] K. Zanio, Semiconductors and semimetals. (Academic Press, 1978).

[2] R. Singh, R. Sivakumar, S.K. Srivastava, and T. Som, Applied Surface Science, 507, 144958 (2020), https://doi.org/10.1016/j.apsusc.2019.144958.

[3] Y. Sun, C.J. Takacs, S.R. Cowan, J.H. Seo, X. Gong, A. Roy, and A.J. Heeger, Advanced materials, 23(19), 2226-2230 (2011), https://doi.org/10.1002/adma.201100038.

[4] C. Gretener, J. Perrenoud, L. Kranz, C. Baechler, S. Yoon, Y.E. Romanyuk, S. Buecheler, and A.N. Tiwari, Thin Solid Films, 535, 193-197 (2013), https://doi.org/10.1016/j.tsf.2012.11.110.

[5] C. Battaglia, S.M. De Nicolas, S.De Wolf, X. Yin, M. Zheng, C. Ballif, and A. Javey, Applied Physics Letters, 104(11), 113902 (2014), https://doi.org/10.1063/1.4868880.

[6] Zh.I. Alferov, Semiconductors, 32, 1-14 (1998), https://doi.org/10.1134/1.1187350.

[7] V.V. Brus, Solar Energy, 86, 786-791 (2012), https://doi.org/10.1016/j.solener.2011.12.009.

[8] H.A. Mohamed, Journal of applied Physics, 113(9), 093105 (2013), https://doi.org/10.1063/1.4794201.

[9] E. Barsoukov, and J.R. Macdonald (Eds.). Impedance spectroscopy: theory, experiment, and applications. (John Wiley \& Sons, 2018).

[10] J. Chen, and N.G. Park, Advanced Materials, 31(47), 1803019 (2019), https://doi.org/10.1002/adma.201803019.

[11] M.N. Solovan, V.V. Brus, P.D. Maryanchuk, M.I. Ilashchuk, and Z.D. Kovalyuk, Semicond. Sci. Technol. 30, 075006 (2015), https://doi.org/10.1088/0268-1242/30/7/075006.

[12] L.N. Skvortsova, V.N. Batalova, K.A. Bolgaru, I.A. Artyukh, and A.A. Reger, Russian Journal of Applied Chemistry, 92(1), 159-165 (2019), https://doi.org/10.1134/S10704272190100221.

[13] P.M. Gorley, Z.M. Grushka, V.P. Makhniy, O.G. Grushka, O.A. Chervinsky, P.P. Horley, Yu.V. Vorobiev, and J. Gonzalez-Hernandez, Phys. Stat. Sol. (C), 5, 3622-3625 (2008), https://doi.org/10.1002/pssc.200780149.

[14] V.V. Brus, M.I. Ilashchuk, Z.D. Kovalyuk, P.D. Maryanchuk, K.S. Ulyanytsky, Semicond. Sci. Technol. 26, 125006 (2011), https://doi.org/10.1088/0268-1242/26/12/125006.

[15] E.H. Nicollian, and A. Goetzberger, Bell System Tech. J. 46, 1055-1133 (1967), https://doi.org/10.1002/j.15387305.1967.tb01727.x.

[16] V.V. Brus, Semicond. Sci. Technol. 27, 035024 (2012), https://doi.org/10.1088/0268-1242/27/3/035024.

[17] M.P. Hughes, K.D. Rosenthal, N.A. Ran, M. Seifrid, G.C. Bazan, and T.Q. Nguyen, Advanced Functional Materials, 28(32), 1801542 (2018), https://doi.org/10.1002/adfm.201801542.

[18] M.M. Shehata, and K. Abdelhady, Applied Physics A, 124(9), 591 (2018), https://doi.org/10.1007/s00339-018-2006-6.

[19] V.V. Brus, Semicond. Sci. Technol. 28, 025013 (2013), https://doi.org/10.1088/0268-1242/28/2/025013.

[20] T. Kamas, V. Giurgiutiu, and B. Lin, Smart Materials and Structures, 24(11), 115040 (2015), https://doi.org/10.1088/0964$1726 / 24 / 11 / 115040$.

\section{ЕЛЕКТРИЧНІ ТА ФОТОЕЛЕКТРИЧНІ ВЛАСТИВОСТІ ГЕТЕРОПЕРЕХОДІВ МоО $\mathrm{M}_{\mathrm{x}} / \mathrm{n}_{-\mathrm{Cd}} \mathrm{Cd}_{1-\mathrm{Zn}} \mathrm{Zn}_{\mathrm{x}} \mathrm{Te}$ М.М. Солован ${ }^{\text {a }, ~ А . І . ~ М о с т о в и и ̆ ~}{ }^{\mathrm{a}}$, Г.П. Пархоменко ${ }^{\mathrm{a}}$, В.В. Брус ${ }^{\mathrm{b}}$, П.Д. Мар'янчук ${ }^{\mathrm{a}}$ \\ аЧернівецький національний університет імені Юрія Федьковича вул. Кочюбинського 2, 58012 Чернівиі, Україна \\ ${ }^{b}$ Університет імені Назарбаєва, 53 Кабанбай Батир, 010000, Нур-Султан, Казахстан}

У роботі представлено результати досліджень оптичних і електричних властивостей напівпровідникових гетеропереходів $\mathrm{MoOx} / \mathrm{n}-\mathrm{Cd}_{1-\mathrm{x}} \mathrm{Zn}_{\mathrm{x}} \mathrm{Te}$ виготовлених нанесенням плівок $\mathrm{MoO}_{\mathrm{x}}$ на попередньо поліровану поверхню пластин $\mathrm{n}-\mathrm{Cd}_{1-\mathrm{x}} \mathrm{Zn}_{\mathrm{x}} \mathrm{Te}$ 
(розміром $5 \times 5 \times 0,7$ мм³ $^{3}$ в універсальній вакуумній установці Leybold - Heraeus L560 за допомогою реактивного магнетронного розпилення мішені чистого Мо у середовищі аргону і кисню. Такі дослідження мають велике значення для подальшої розробки високоефективних приладів на основі гетеропереходів для електроніки і оптоелектроніки. Виготовлені гетеропереходи $\mathrm{MoO}_{\mathrm{x}} / \mathrm{n}-\mathrm{Cd}_{1-\mathrm{x}} \mathrm{Zn}_{\mathrm{x}} \mathrm{Te}$ володіють великою висотою потенціального бар'єру при кімнатній температурі $\left(\varphi_{0}=1,15 \mathrm{eB}\right)$, яка значно перевищує аналогічний параметр для гетеропереходу $\mathrm{MoO}_{\mathrm{x}} / \mathrm{n}-\mathrm{CdTe} \quad\left(\varphi_{0}=0,85 \mathrm{eB}\right)$. Експериментально визначений температурний коефіцієнт зміни висоти потенціального бар'єра становив $d(\varphi 0) / d T=-8,7 \cdot 10^{-3} \mathrm{eB} / \mathrm{K}$, даний параметр більший у чотири рази від температурного коефіцієнта зміни висоти потенціального бар'єра для гетероструктур $\mathrm{MoO}_{x} / \mathrm{n}-\mathrm{CdTe}$. Більше значення висоти потенціального бар'єру гетеропереходу $\mathrm{MoO}_{x} / \mathrm{n}-\mathrm{Cd}_{1-\mathrm{x}} \mathrm{Zn} \mathrm{x}$ Te обумовлене формуванням електричного диполя на гетерограниці, через збільшення концентрації поверхневих станів в порівнянні з гетероструктурою $\mathrm{MoO}_{\mathrm{x}} / \mathrm{n}$-CdTe, а це очевидно пов'язано з наявністю атомів цинку в області просторового заряду та на металургійній межі поділу гетерограниці. В гетеропереходах $\mathrm{MoO}_{\mathrm{x}} / \mathrm{n}-\mathrm{Cd}_{1-\mathrm{x}} \mathrm{Zn} \mathrm{n}_{\mathrm{x}} \mathrm{Te}$ домінуючими механізмами струмопереносу є генераційно-рекомбінаційний та тунельно-рекомбінаційний за участі поверхневих станів та тунельний при прямому зміщенні та тунелювання при зворотньому зміщенні. Встановлено, що гетеропереходи $\mathrm{MoO}_{\mathrm{x}} / \mathrm{n}-\mathrm{Cd} \mathrm{d}_{1-\mathrm{x}} \mathrm{Zn}_{\mathrm{x}} \mathrm{Te}$, які володіють такими фотоелектричними параметрами: напруга холостого ходу $V_{o c}=0,3 \mathrm{~B}$, струм короткого замикання $I_{s c}=1,2 \mathrm{~mA} / \mathrm{cm}^{2}$ і коефіцієнт заповнення $\mathrm{FF}=0,33$ при інтенсивності освітлення $80 \mathrm{mBT} / \mathrm{cm}^{2} \epsilon$ перспективними для виготовлення детекторів різного типу випромінювань. Виміряний і досліджений імпеданс гетеропереходу $\mathrm{MoO}_{\mathrm{x}} / \mathrm{n}-\mathrm{Cd}_{1-\mathrm{x}} \mathrm{Zn}_{\mathrm{x}} \mathrm{Te}$ при різних зворотних зміщеннях, що дало змогу визначити розподіл густини поверхневих станів та характеристичний час їх перезарядки, які зменшуються при зростанні зворотного зміщення.

КЛЮчОВІ СЛОВА: гетероперехід, оксид молібдену, $\mathrm{Cd}_{1-\mathrm{x}} \mathrm{Zn}_{\mathrm{x}} \mathrm{Te}$, імпеданс, поверхневі стани 